\title{
NUMERALS AND LETTERS IN CONNECTION WITH ARTICLES OF COMMERCE.
}

The usual rule that words or symbols that are descriptive of an article of commerce, or indicate its quality, or grade of excellence, will not be protected by the courts, as trade names or marks, holds both of numerals and letters, and the question of description is one of fact for the courts to decide.

It has been held ${ }^{1}$ that numerals can not be a true trade symbol or mark, that they indicate quality, style, or kind, and that any tradesman may use numerals to describe his goods, though the same numerals have been used by another tradesman. Thus 27 was not protected, when used in connection with mattresses.

The statement above made, however, is far too broad. Of course, when numerals are indicative merely of quality, ${ }^{2}$ they are publici juris and others may employ them with equal truth. For example, when petroleum manufacturers use 600 on their barrels, to indicate the number of degrees of heat to which the goods are subjected to the fire test, and associate letters with the numerals to indicate quality, a manufacturer, who places $600 \mathrm{~W}$. on his barrel, has no such exclusive right as to prevent another from using $600 \mathrm{~V}$. To permit these symbols to be withdrawn from public use would give a most unjust monopoly, calculated greatly to injure others. ${ }^{3}$ Again, the Patent Office refused to register 1904 for coffee, ${ }^{4}$ as it would indicate when the coffee was grown and thus be descriptive of its age. The numeral 9000 on black beetled cloths was also held a mere mark of quality. ${ }^{\circ}$ Especially is the numeral held to be descriptive, when it is already in use and known to the trade, in connection with given styles of goods, as 60 and 70 applied to nails. ${ }^{6}$

On the other hand, numerals, when arbitrarily selected ${ }^{7}$ by a tradesman to describe his own goods, are clearly a good trade mark and have been so held and protected when the use by another enables him to palm off his goods. Thus I4O was registered as a trade symbol $^{8}$ for umbrellas, 830 was protected as used on hose, ${ }^{9} 30$ and III as used on nails, ${ }^{10} 303$ on Gillott's pens, ${ }^{11} 5^{23}$ on cloths, 35 on carte de visite mounts or cards. ${ }^{12}$ The fact that the court dees not 
know the meaning of the number may be evidence of its arbitrariness as mark 2008 was protected on grey shirting. ${ }^{13}$ When a series of numerals is used by a tradesman, the use of the same series by another on the same character of goods may be deceptive ${ }^{14}$ and so to be restrained. Especially is this the case where the numerals stand for ownership, in combinations with words or letters. So the use of the words, Homoepathic Specifics, was enjoined, for eleven reme.dies with the same numbers as the plaintiff employed ${ }^{\mathbf{1 5}}$ though, in another case, no injunction was given against the use of the words, Hilton's Specifics, numbered I to I4, at the suit of the makers of Humphrey's Specific Medicines, ${ }^{16}$ who used for different medicines a series of numbers from I to 35 .

Even when the number itself is publici juris, ${ }^{17}$ as $1 / 2$ on cigarettes of mixed tobacco, it may be protected, when "printed or painted in some special form not in ordinary use," and when the defendant had copied the "form, size, color, and style." In other words, the use of the same numeral may be a significant element in cases where the plaintiff's title rests on accumulated resemblances of the defendant's goods, ${ }^{18}$ the so-called "dressing up" cases. A fair summing up of the law with reference to numerals is that, while these are generally descriptive of quality of the article of commerce and it is difficult to give them the effect of indicating origin or ownership, yet this may be done and, arbitrarily chosen and solely used to point out plaintiffs' goods, even bare numbers may be protected as trade symbols and this protection will be clearly due, when a whole series of numbers is copied, or when the numbers are associated with other features which are also copied.19

Sebastian is probably correct, however, in saying that if "the plaintiff's numeral were printed in an ordinary style and the defendant could show any reason for desiring to use the number in the course of his business, which was not necessarily attributable to a wish to appropriate the plaintiff's custom, no relief would be granted against him."20

As to letters, the general rule is that a single letter will not be protected as a trade symbol. ${ }^{21}$ "If one manufacturer may appropriate all the letters and another all the digits it is manifest,". dryly says a Federal judge, "that it will require more than ordinary intelligence for remaining manufacturers to present goods intelligently to the trade." Especially is this true, when the tradesmen use other distinctive trade marks. Yet we find $\mathrm{X}$ admitted to registry, ${ }^{22}$ and $\mathrm{D}$ protected as a trade mark. ${ }^{23} \mathrm{~A}$ single letter in a peculiar 
frame, ${ }^{2 *}$ e.g. $D$ in a lozenge, has been protected. As to the use of two or more letters, there are six classes of cases: (I) where the letters are initials, (2) where they are purely arbitrary, (3) where they convey a meaning through their sound, (4) where the letters are added to a name or symbol, (5) where the letters are printed in a monogram, (6) where they are descriptive of quality.

(I) Where the letters are the initials of the firm name, or of the article's name, they are usually held to be descriptive and not entitled to protection; except in cases of passing off defendants' goods as plaintiffs'. It would seem that as the name of the tradesman is not a trade mark, neither are his initials. ${ }^{25}$ However, if the letters have acquired a secondary and arbitrary meaning, they are entitled to protection, as also if they are deceptively used by the defendant. Especially is this the case when the initials denote a previous owner of the business and are still rightfully used by his successors. Thus N. S., the initials of Nathan Samuel, the founder of the business, were protected against the use of N. \& S. by another tradesman, ${ }^{2 a}$ and B. B. H. stamped on iron by the old firm of Brahmah, Barrows, Hall, were held to have become a mere arbitrary symbol and to have ceased to indicate any particular person $; 27$ M. C., originally standing for Morgan Carmarthen, were also held to be a good trade mark. ${ }^{28}$ If the defendant's conduct is deceptive, he may be enjoined even from such use of his own initials. Thus John Baldrick of Londonderry was restrained from using J. B. D. in an oval at the suit of a Parisian firm, which used G. B. D. in an oval. ${ }^{20}$ M. \& C. in a circle ${ }^{30}$ was also protected. After the dissolution of a firm, an agreement by the partners not to use the old trade mark, consisting of the letters $P$. \& O. in a scroll bearing an inscription, was broken by the use, on the part of one of the partners, of the letters P. S. \& Co., ${ }^{31}$ in a similar scroll. The letters C. A. P. used as an abbreviation for Cream Acid Phosphates are held to be a good trade symbol, and restraint is given against using the same to denote Calcium Acid Phosphate. ${ }^{32}$ Smith Brothers, making "S. B. Cough drops," suffer no actionable injury from Burt \& Sindele, who label their goods "Cough Drops B. \& S. ${ }^{33}$ No injunction was given William Rosenthal against the use of the letters W. R. by Waterhouse Reynolds \& Co., they not being shown to be guilty of fraud. ${ }^{34}$

(2) Purely arbitrary combinations of letters are protected. Thus $\mathrm{K}$. K. was held to be too like $\mathrm{XX}$ for use on knives made to be sold in India, ${ }^{35}$ where the latter symbols were not known as 
descriptive. So, too, Clark's O. N. T. spool cotton: is held to be infringed by Clark's N. E. W. spool cotton. ${ }^{38}$ L. L. for whiskey is protected, since the letters mean nothing by themselves and were adopted, because the plaintiffs once sold a lord lieutenant whiskey. ${ }^{37}$ The use of the letters by another would cause the public to think that he sold the plaintiffs' goods, or had their permission to use the letters. So L. P. C. in a shield are infringed by L. P. in a shield, ${ }^{38}$ and a tradesman who places $G$. F. on ribbons is granted an injunction against another, ${ }^{30}$ who uses $G$. \& F., with the ampersand much smaller than the initials, though he registered and used on other goods the three characters of the same size. Iron bars marked W. C. in an oval and sent to Turkey are protected against those made for the same trade and marked W. O. in an oval. ${ }^{40}$ O. K. is allowed registry for root beer. ${ }^{41}$

(3) Where the letters convey a meaning through their sound they are usually descriptive, and so not valid trade marks. For example, the plaintiff uses IXL on cutlery, ${ }^{42}$ and the defendant Non X. L. L., still others using XLALL and XLNT, and no injunction is given, on the ground that letters whose sound conveys a descriptive meaning that might have been expressed by words in common use having the same sound, could not be appropriated by any one, unless by use they had acquired a secondary meaning, as the distinctive mark of a particular manufacturer. In England, however, IXL has been held a good trade mark. ${ }^{43}$

(4) The addition of letters to names does not make a trade symbol which the court will protect, if the added letters are the initials of the names. ${ }^{44}$. Thus S. S. Swift's Syphilitic Specific ; ${ }^{45}$ Parsons' Purgative Pills, P. P. P. $;^{46}$ Conduraugo Ointment, C. $O . ; 7$ are not good trade marks. Arbitrary letters may, of course, be an element of a mark, and so may initials, whether they have a descriptive meaning or an arbitrary one. Thus T. H. H., B. H. H. ${ }^{48}$ and $\mathrm{S}$. \& $\mathrm{H}^{40}$ with a crown were treated as valid trade marks. A cross-shaped label with the letters C. B. for C. Busson \& Co., was protected against a similar label with the letters C. S. for Carlisle Sons \& Co. ${ }^{50}$ In early cases, the court protected the use with the plaintiff's firm name of the letters J. H., the initials of John Heppel, the plaintiff's principal workman, ${ }^{\mathrm{s}}$ and $\mathrm{H}$. H. with the name of a formerly patented article. ${ }^{52}$ The fact that the combination of letters and symbols indicates not only the particular manufacturer, but also the quality and pattern of goods, does not deprive it of protection..$^{53}$ Thus where the plaintiff marked the 
parts of plows made by him R. N. F. with numerals I to $I 7$, the defendant was restrained from using the same combinations. Chas. Bayer long marked his corsets with the letters C. B. and a star, and, in both an Irish and a Scotch case, received protection against Connell Brothers of Dublin, who stamped their corsets with a star and the letters C. B. \& Co., the $\&$ Co. being very small, or with C. B. D., which last letter might escape observation. ${ }^{54}$

(5) Initials formed in a monogram may be infringed by copying the monogram. ${ }^{55}$ Thus the plaintiff uses his initials A. G. on his goods in a peculiar monogram and the defendant is restrained from using a similar monogram of A. G. Co. where $\mathrm{Co}$. is in small letters and might be taken for part of the ornamentations. ${ }^{58}$

(6) Letters, descriptive of quality and not used primarily to denote ownership, are of course not protected by the courts. ${ }^{57}$ In a leading case, it was held by Mr. Justice Field, that A. C. A. used on ticking were only used to indicate quality, and so were not a trade mark. The letters themselves, it was true, did not suggest anything, but merely significant as used to indicate quality ${ }^{58}$ If purchasers read the name of the company, the letters give no additional information, as to origin; if they do not read it, the letters are unintelligible. So L. L. Sheeting was not protected, for it was known as a name for sheetings of a particular grade and was used by another before by the plaintiff, and by still third parties with his acquiescence. The court said that it was doubtful whether letters can represent both quality and origin. ${ }^{53}$

Bernard C. Steiner. 


\section{APPENDIX.}

I. Smith \& Davis v. Smith, 89 Fed. 486; see also Coats v. Merrick Thread Co., 45 Off. Gaz. 347, 63 Off. Gaz. 1531.

2. Eagle Percil Co., Ex parte, Io Off. Gaz. $98 \mathrm{r}$; Carver v. Bowker, Cox Dig. 58r.

3. Vaccum Co. v. Climax Co., I20 Fed. 254.

4. Schotten \& Co., Ex parte, I05 Off. Gaz. 1532.

5. Barloze v. Gobindram, Ind. I. R. 24 ; Calc. 364 .

6. Am. Button Co. v. Anthony, I5 R. I. 338 .

7. Lawrence \& Lowell, I29 Mass. 325.

8. Dawes \& Fanning, Ex parte, Off. Gaz. 27.

9. Shaw Co. ข. Mack, I2 Fed. 707.

10. Anerican Button Co. v. Anthony, I5 R. I. 338.

II. Gillott v. Esterbrook, 48 N. Y. 374.

12. Collins v. Reynolds, 7 Abb. N. C. I7.

13. Ralli v. Fleming, Ind. L. R. 3 Calc. 4 I 6.

14. Carver v. Bowker, Cox Dig. 58r ; Collins v. Reynolds, 7 Abb. N. C. I7.

15. Humphreys v. Wenz, I4 Fed. 250.

16. Humphreys v. Hilton, 67 Off. Gaz. 193.

17. Kinney v. Allen, Fed. Cas. 7826.

18. Dennison Co. v. Thomas, 94 Fed. 65 r.

19. Boardman v. Meriden Co., 30 Conn. 402.

20. Law of Trademarks (4th ed.), 79.

2I. Stevens v. Don, I2I Fed. I7I; A used on crash toweling. See Mitchell, $R e, 7$ R. P. C. 36. Ferguson v. Davol Mills, 2 Brewst. 314, K not protected on Silesias.

22. English, Ex parte, Cox Dig. 342. $\mathrm{X}$ brooms.

23. Hornsby v. Hudson, II N. S. W. L. R. Eq. 148.

24. Dutcher Temple Co., Re, Cox Dig. $37 \mathrm{I}$.

25. Burt v. Smith, 7I Fed. I6r.

26. Frank $v$. Sleeper, I50 Mass. 583.

27. Hall v. Barrozes, 1o Jur. N. S. 55 ; Barrows, Ex parte, 1877 W. N. IIg.

Barrows, Re, L. R. 5 Cl. D. 353 .

28. Motley v. Downman, 3 M. \& Cr. I.

29. Maréchal v. McColgan, I8 R. P. C. 262. He alleged D stood for Derry.

30. Moet v. Clybouw, Cox Dig. 533.

31. Osbourne v. Paton, Sebastian on T. M. 193.

32. Provident Works v. Canada Co., 2 O. L. R. I82; overruled by 4 O. L.

$R$. 545, when it was shown that most dealers did not know meaning of plaintiffs' letters.

33. Burt v. Smith, 7I Fed. 16r.

34. Rasenthal v. Reynolds, 9 R. P. C. $1 \& 9$.

35. Copley v. Kirk, 84 L. T. Jour. 40. 
36. Clark Co. v. Armitage, 76 Off. Gaz. I4I9.

37. Kinahan v. Bolton, 15 Ir. Ch. 75.

38. Hammond v. Brunker, 9 R. P. C. 30I.

39. Giron v. Gartner, 57 Off. Gaz. 1430.

40. Crawshay v. Thompson, 4 Man. \& Gr. 357.

4I. Heinle, Ex parte, Newt. Dig. 17.

42. Wostenholm v. Woolhouse, I4 V. L. R. 963.

43. Marshall v. Sidebotham, I8 R. P. C. 43.

44. Esterbrook Steel Pen Co., Ex parte, 97 Off. Gaz. 1597; Dundas Dick

\& Co., Ex parte, 9 Off. Gaz. 538 .

45. Szerift, Ex parte, Newt. Dig. Ig2.

46. Johnson, Ex parte, 2 Off. Gaz. 314.

47. Blackslee, Ex parte, Cox Dig. 376.

48. Barrows, Ex parte, I877 W. N. IIg. Barrows v. Pelsall Co, Cox

Dig. 530. In the latter case Boaz Bloomer \& Sons were restrained from using B. B. S. with a crown.

49. Hopkins v. Hitchcock, I4 C. B. N. S. 65.

50. Carter v. Carlisle, $3 \mathrm{I}$ Beav. 292.

51. Millington $v$. Fox, 3 M. \& Cr. 338 .

52. Ransome v. Benthall, 3 L. J. Ch. I6r.

53. Ransome v. Graham, 5I L. J. Ch. 897.

54. Bayer v. Connell, 16 R. P. C. I57 (Irish); Bayer v. Baird, 15 R. P. C. 615 (Scotch).

55. Consolidated Co. v. Thomas, Cox Dig. 665.

56. Godillot v. Am. Grocery Co., 71 Fed. 873 .

57. Dennison Co. v. Thomas, 14 Fed. $65 \mathrm{I}$.

58. Amoskeag $M f g$. Co. v. Trainer, I7 Off. Gaz. I217.

59. Lazerence Mfg. Co. v. Tenn. Co., 3I Fed. 771; 55 Off. Gaz. I528; the court held L. L. meant 4 yards goods, and showed that the complainant made Shawmut LL 8, and Lawrence L. L., and the defendant Cumberland L. L. 